\title{
A multicentre survey on the sociodemographic characteristics of Italian elderly inmates
}

Graziamaria Corbi', Carlo Alberto Romano², Carlo Pietro Campobasso², Anna Convertini ${ }^{4}$, Liliana Dassisti ${ }^{4}$, Antonella Rita Fanizza ${ }^{4}$, Federica Misce $^{4}$, Luisa Ravagnani², Luigi Ferrannini ${ }^{5}$, Ignazio Grattagliano ${ }^{4}$

${ }^{1}$ Department Medicine and Health Sciences, University of Molise, Campobasso, Italy; ${ }^{2}$ Law Department University of Brescia, Italy; ${ }^{3}$ Department of Experimental Medicine, University of Campania "L. Vanvitelli", Naples, Italy; ${ }^{4}$ Department of Educational Sciences, Psychology and Communication, University of Bari "Aldo Moro", Bari, Italy; ${ }^{5}$ Facoltà di Medicina e Chirurgia, Università di Genoa, Italy

Received: January 5, 2020

Accepted: February 25, 2020

\section{Correspondence}

Graziamaria Corbi

Department Medicine and Health Sciences,

University of Molise, via De Sanctis snc, 86100

Campobasso, Italy

E-mail: graziamaria.corbi@unimol.it

\section{Conflict of interest}

The Authors declare no conflict of interest

How to cite this article: Corbi G, Romano CA, Campobasso CP, et al. A multicentre survey on the sociodemographic characteristics of Italian elderly inmates. Journal of Gerontology and Geriatrics 2020;68-136-45. https://doi. org/10.36150/2499-6564-409

C Copyright by Società Italiana di Gerontologia e Geriatria (SIGG)

\section{(c) (1) (9) $\odot$}

\section{OPEN ACCESS}

This is an open access article distributed in accordance with the CC-BY-NC-ND (Creative Commons Attribution-NonCommercial-NoDerivatives 4.0 International) license. The article can be used by giving appropriate credit and mentioning the license, but only for non-commercial purposes and only in the original version. For further information: https://creativecommons.org/licenses/by-nc-nd/4.0/deed.en
Background \& aim. In 2017, Italian inmates 60-69 years old were 3700 , while 776 had an age $>=70$ years. This article aimed to analyse the socio-demographic characteristics and types of crimes committed by elderly subjects restricted in different Italian prisons.

Methods. A survey has been conducted in 8 penitentiary institutes: 4 located in Lombardy, and 4 in Apulia. The participation was anonymous and voluntary. By using a standardised format, age, gender, nationality, marital status, last occupation, type of crime, and duration of the punishment were assessed. In the case of previous convictions, additional data were also collected. All records were analysed as aggregates to guarantee privacy preservation.

Results. The population was mainly represented by males (93.6\%), married or living with a partner $(46.8 \%)$. The most prevalent crimes committed by the elderlies belongs to the category against the property $(33.1 \%)$ followed soon after by those against the person $(27.7 \%)$, other offences (14\%), drug-related (13.8\%) and mafia-type crimes (11.7\%). The Southern inmates were more frequently responsible for crimes against the person (38\%), while property crimes $(61 \%)$ were more recurrent in the Northern inmates. Sixty-four prisoners $(68.8 \%)$ were already found guilty in the past for other misconducts. The Northern inmates were more frequently recidivist, with a higher number of previous convictions $(p=0.010)$ and detentions $(p=0.012)$ compared to the Southern prisoners.

Conclusions. Committing crimes in older age is strongly different from being a criminal in young or adult age, especially for the complexity that per se characterizes the older population.

Key words: elderly, prison, crimes, epidemiological study, recidivism, inmates

\section{INTRODUCTION}

Eurostat 2019 data show that the population of the European Union amounted to 513.5 million people, of whom almost 1/5 (19.7\%) were aged 65 and over. In the European Union the highest percentage of people aged >=65 was found in Italy (22.6\%), Greece (21.8\%) and Germany (21.4\%) ${ }^{1}$. According to the 2018 report of the Italian Institute of Statistics (ISTAT), out of 
60 million 484 thousand Italian residents, the individuals aged $>=65$ are more than 13.5 million and represent the $22.3 \%$ of the entire population; those aged $>=80$ are 4.1 million $(6.8 \%$ of the total) while subjects aged $>=90$ are 727 thousand (1.2\% of the total). Centenarians amount approximately to 17 thousand people ${ }^{2}$. Moreover, in Italy, the number of elderlies has been predicted to rise from $26.1 \%$ in 2030 to $33.1 \%$ in $2050^{3}$.

Fifty- or 55-years old subjects are generally defined "elderly" or "geriatric prisoners" ${ }^{4}$, but there are still controversial opinions in defining the age limits for elder inmates ${ }^{5}$. Based on the 2017 ISTAT report, the Italian prisoners between 60 and 69 years old are approximately 3.700 subjects, in comparison to a total of 776 prisoners with an age of 70 years or more ${ }^{6}$. Life in prison is strongly risky especially for the elderly.

According to Aday ${ }^{7}$, the stressful conditions in prison may lead to an accelerated process of ageing. Living in a closed environment like a prison can change people, causing depersonalization and destructuration of the self. Prisoners lose the property of material objects, the ability of self-determination, their privacy, and also sexual identity can be challenged ${ }^{8}$. Depression and suicide are two of the main problems that might occur because of freedom restriction. Depression is pretty common in elder inmates ${ }^{9}$. It can be easily explained by the deep feeling of isolation and loss caused by the imprisonment. Men and women in prison for the rest of their life might easily experience fear, rage, shame, and loneliness ${ }^{7}$. Most of the elder women inmates, in particular, show frequently several health problems like breast cancer, menopause, and osteoporosis ${ }^{10}$. Depression, harassment, feeling of insecurity, falls or difficulties linked to cognitive impairment can be other health-related problems ${ }^{11}$. Indeed, it should be underlined that even gender can cause disadvantages for elderly inmates, and it is more evident for women prisoners ${ }^{12}$.

Based on the above elements, for elderly detention is a crucial event due to the recurrence or worsening of several diseases and risk factors. In fact, detention has been defined as pathoplastic since it can raise previous fragile balance conditions ${ }^{13,14}$. In Italy, a Treatment and Observational Group (TOG) was born in 2003 to assure an adequate health status to the prisoners. This Group is managed by the Director of the facility and composed of the Administrative personal or, if required, by experts in medicine and psychology. Main TOG's purpose is to understand the peculiar needs of each prisoner for planning and acting a program that fits with each request ${ }^{15}$. According to Article 1 of the Italian Prison Code, the treatment of prisoners must be respectful of the fundamental human rights and must guarantee dignity for every single person. A new position, widely accepted among the scientific community, recommends that the "custodial sentence should no longer be the principal sanction for any kind of crime" ${ }^{16}$.

Up to date, no data are available in the literature on the Italian elderly inmates. Therefore, this study aimed to analyse the socio-demographic characteristics and types of crimes committed by elderly subjects restricted in different Italian prisons along with their health conditions.

\section{MATERIALS AND METHODS}

An observational transversal multi-centric survey has been conducted including eight penitentiary institutes. Four penitentiary institutes were located in Lombardy, one of the most populated regions of the Northern part of Italy (Brescia, Bergamo, Cremona, Mantova) and other four penitentiary institutes in Apulia (Bari, Taranto, Foggia, Lecce), one of the most populated regions of Southern Italy. The study was conducted from September to December 2018. The participation in the survey was anonymous and voluntary. By using a standardised format, the survey was designed to assess for each participant: age, gender, nationality, marital status (single/married), last occupation (self-employed/ employee), characteristics of the current imprisonment (type of crime for which the individual was convicted, age at the time of crime commission, duration of the punishment). In the case of previous convictions, additional information was also collected such as the age at the time of conviction and period already spent in jail or in alternative detention measures, pathological addictions, and diseases. All data were analysed as aggregates to guarantee the privacy preservation.

\section{Statistical ANALYSIS}

Descriptive statistics (mean \pm standard deviation, frequency, and average) were used to analyse the results. The Pearson $\chi^{2}$-test was used to measure the difference between the categorical variables. The t Student test or one-way ANOVA with post-hoc analysis was used to compare the groups for continuous variables. Data were analysed using the SPSS 23.0 statistics package (SPSS, Inc., Chicago, Illinois-USA). Statistical significance was accepted at a p-value $<0.05$.

\section{RESULTS}

All the subjects over 60 years old imprisoned in the considered jails answered to the survey. Therefore, the total study population consisted of 94 inmates (88 males, 6 females) with a mean age of $67.1 \pm 3.7$ years (range 61-78), mostly Italians except 4 foreigners. Sixtythree inmates $(67 \%)$ out of 94 were coming from the 
Southern penitentiary institutes, while 31 (33\%) from the Northern jails.

The total study population was mainly represented by males $(93.6 \%, n=88)$, married or living with a partner $(46.8 \%, n=44)$, with a mean length of condemn of $164.82 \pm 196.93$ months (minimum length was of 7 months, maximum length was the life imprisonment). In 59 cases $(62.77 \%)$ the inmates had already spent $115.18 \pm 116.57$ months in prison.

Table I shows the main characteristics of the population divided by Southern and Northern distribution. By comparing the Northern versus the Southern sample no differences were found for age $(p=0.437)$, gender $(p=0.660)$ and civil status $(p=0.051)$. However, in the Southern the most part of the inmates was married or living with a partner (52.4\%) in respect to the Northern jails where the inmates were equally married (35.5\%) or divorced (35.5\%, Table I). By comparison, the inmates from the South (Apulia) had longer condemns (206.30 \pm 223.78 vs $80.52 \pm 75.96, p=0.003)$ than the prisoners of Lombardy (Tab. I).

Table II reports the distribution of each different type of crimes in the study population. All were sub-grouped in five main categories according to the Italian Penal code. The most prevalent crimes committed by the elderly belong to the category against the property (33.1\%) followed soon after by those against the person $(27.7 \%)$, other crime (14\%), drug-related crimes (13.8\%), and mafia-type crimes (11.7\%, Tab. II).

Figure 1 shows the distribution of the 5 main categories in the study population. A significant difference ( $p<0.0001$ ) was found between the two groups, with the Southern inmates more frequently responsible of crimes against the person (38\%), while property crimes $(61 \%)$ were more recurrent in the Northern inmates. In particular the Southern inmates were more often responsible of homicides (20.6\%), while robbery and theft were more numerous in the Northern inmates (25.8\% and $19.4 \%$ respectively). It is worth of mentioning that 10 out of 94 inmates (10.6\%) were responsible of more than 1 crime, without differences in the two groups.

A second analysis was then performed comparing our data with those provided by the 2017 Report of the Italian Justice and Law Ministry on elderly inmates ${ }^{17}$ (Fig. 2).

In 2017 the Italian Justice and Law Ministry reported that 717 elderlies were imprisoned in Lombardy jails, while 184 were in Apulia region. Therefore, our study included the $4.32 \%$ of the elderly inmates from the Lombardy and the $34.78 \%$ of the elderly inmates from the Apulia region. These differences $(p<0.0001)$ are mainly related to the different number of the jails recruited in the study (4 out 18 [22.2\%] of the Lombardy and 4 out the 11 [36.4\%] of the Apulia). After stratification by age (60-69 years vs $>=70$ years old), in our survey no differences $(p=0.265)$ were found between the Northern and Southern inmates. Comparing our data with the 2017 Report of the Italian Justice and Law Ministry, the most part of inmates was aged between 60-69 years old, whereas about $30 \%$ of the Southern subjects were $>=70$ years old (Fig. 2).

Sixty-four prisoners (68.8\%) were found already guilty in the past for other crimes. The Northern inmates were more frequently recidivist, with a higher number of previous convictions (86.7 vs 60.3\%, $\mathrm{p}=0.010)$ and detentions (80.6 vs 54\%, $p=0.012$ ) compared to the Southern prisoners. A trend of a longer period in jail was also observed in the Northern study group $(81.55 \pm 99.33$ vs Southern $67.57 \pm 112.07, \mathrm{p}=0.557$ ).

Only 17 inmates (18\%) out of the 94 totally recruited in the study reported addiction to drugs, alcohol or gambling (Fig. 3), with no differences between the groups $(p=0.267)$. In all cases the most prevalent addiction was represented by the drug abuse (Fig. 3).

Finally, in regard of the health status, the Southern inmates were affected by a higher number of diseases compared to Northern individuals $(1.27 \pm 1.15 \mathrm{vs}$ $0.35 \pm 0.71, p<0.0001)$. Figure 4 shows the prevalence of diseases in the overall study population. The

Table I. Main characteristics of the Southern and Northern study groups.

\begin{tabular}{|l|l|c|c|c|}
\hline & & \multicolumn{3}{|c|}{ Penitentiary institutes } \\
\hline & & $\begin{array}{c}\text { Southern } \\
(\mathbf{n}=\mathbf{6 3})\end{array}$ & $\begin{array}{c}\text { Northern } \\
\mathbf{( n = 3 1 )}\end{array}$ & $\mathbf{P}$ \\
\hline Age, (years) mean + SD & & $67.3 \pm 4.1$ & $66.7 \pm 2.9$ & 0.437 \\
\hline Gender, (M/F) n (\%) & & $58 / 5(92.1 / 7.9)$ & $30 / 1(96.8 / 3.2)$ & 0.660 \\
\hline \multirow{3}{*}{ Civil status, n (\%) } & Unmarried celibate & $4(6.3)$ & $8(25.8)$ & 0.051 \\
\cline { 2 - 5 } & Married/partner & $33(52.4)$ & $11(35.5)$ & \\
\cline { 2 - 5 } & Divorced & $25(39.7)$ & $11(35.5)$ & \\
\cline { 2 - 5 } & Widow & $1(1.6)$ & $1(3.2)$ & \\
\hline Length of condemn, (months) mean + SD & & $206.30 \pm 223.78$ & $80.52 \pm 75.96$ & $\mathbf{0 . 0 0 3}$ \\
\hline Previous months in prison, (months) mean + SD & & $67.57 \pm 112.07$ & $81.55 \pm 99.33$ & 0.557 \\
\hline
\end{tabular}


Table II. Distribution of crimes in the Southern and Northern study groups.

\begin{tabular}{|c|c|c|c|c|}
\hline \multirow[t]{2}{*}{ Categories } & \multirow[t]{2}{*}{ Crimes } & \multicolumn{3}{|c|}{ Penitentiary institutes } \\
\hline & & $\begin{array}{c}\text { All } \\
(n=94)\end{array}$ & $\begin{array}{c}\text { Southern } \\
(\mathrm{n}=63)\end{array}$ & $\begin{array}{c}\text { Northern } \\
(\mathrm{n}=\mathbf{3 1})\end{array}$ \\
\hline \multirow{8}{*}{$\begin{array}{l}\text { Property crimes, n } \\
\text { (\%) }\end{array}$} & Robbery & $9(9.6)$ & $1(1.6)$ & $8(25.8)$ \\
\hline & Theft & $9(9.6)$ & $3(4.8)$ & $6(19.4)$ \\
\hline & Handling stolen goods & $4(4.3)$ & $2(3.2)$ & $2(6.5)$ \\
\hline & Money laundering & $3(3.2)$ & $1(1.6)$ & $2(6.5)$ \\
\hline & Swindling & $3(3.2)$ & $2(3.2)$ & $1(3.2)$ \\
\hline & Extortion & $2(2.1)$ & $2(3.2)$ & $0(0)$ \\
\hline & Counterfeit & $1(1.1)$ & $1(1.6)$ & $0(0)$ \\
\hline & Total & 31 (33.1) & 12 (19.2) & $19(61.4)$ \\
\hline \multirow{6}{*}{$\begin{array}{l}\text { Crimes against the } \\
\text { person, } n(\%)\end{array}$} & Homicide & $13(13.8)$ & $13(20.6)$ & $0(0)$ \\
\hline & Sexual harassment & $7(7.4)$ & $5(7.9)$ & $2(6.5)$ \\
\hline & Attempted murder & $4(4.3)$ & $4(6.3)$ & $0(0)$ \\
\hline & Private violence & $1(1.1)$ & $1(1.6)$ & $0(0)$ \\
\hline & Brawl & $1(1.1)$ & $1(1.6)$ & $0(0)$ \\
\hline & Total & $26(27.7)$ & $24(38)$ & $2(6.5)$ \\
\hline \multirow[t]{10}{*}{ Others, n (\%) } & $\begin{array}{l}\text { Illicit possession of } \\
\text { weapons }\end{array}$ & $3(3.2)$ & $1(1.6)$ & $2(6.5)$ \\
\hline & $\begin{array}{l}\text { Economic and financial } \\
\text { crimes }\end{array}$ & $2(2.1)$ & $0(0)$ & $2(6.5)$ \\
\hline & Fraudulent bankruptcy & $2(2.1)$ & $1(1.6)$ & $1(3.2)$ \\
\hline & $\begin{array}{l}\text { Missed report a of a lost } \\
\text { credit card }\end{array}$ & $1(1.1)$ & $0(0)$ & $1(3.2)$ \\
\hline & Escape from house arrest & $1(1.1)$ & $1(1.6)$ & $0(0)$ \\
\hline & Concussion & $1(1.1)$ & $1(1.6)$ & $0(0)$ \\
\hline & Occultation of bodies & $1(1.1)$ & $1(1.6)$ & $0(0)$ \\
\hline & $\begin{array}{l}\text { Outrage at a public } \\
\text { official }\end{array}$ & $1(1.1)$ & $1(1.6)$ & $0(0)$ \\
\hline & Smuggling of arms & $1(1.1)$ & $1(1.6)$ & $0(0)$ \\
\hline & Total & $13(14)$ & 7 (11.2) & $6(19.4)$ \\
\hline \multirow{2}{*}{$\begin{array}{l}\text { Drug-related crimes, } \\
\text { n (\%) }\end{array}$} & Illicit traffic in drugs & $13(13.8)$ & $9(14.3)$ & $4(12.9)$ \\
\hline & Total & $13(13.8)$ & 9 (14.3) & $4(12.9)$ \\
\hline \multirow[t]{2}{*}{$\begin{array}{l}\text { Mafia-type activity, } \\
\text { n (\%) }\end{array}$} & $\begin{array}{l}\text { Criminal organization } \\
\text { Mafia-like }\end{array}$ & $11(11.7)$ & $11(17.5)$ & $0(0)$ \\
\hline & Total & $11(11.7)$ & $11(17.5)$ & $0(0)$ \\
\hline
\end{tabular}

Northern and Southern groups differed for the prevalence of heart diseases (except hypertension) that was higher in the Southern group (34.9 vs 6.5\%, $p=0.003$ ) rather than in Lombardy. Disability was assessed by the Local Medico-Legal Committees only for 2 subjects (one from the North and one from the South).

\section{DISCUSSION}

In our knowledge this is the first survey describing the characteristics of elder inmates in Italy, and comparing the situation in some Northern and Southern jails. The main result was represented by a longer length of punishment in the Southern inmates in respect to those of the Northern jails, likely related to a different prevalence of crime type. In fact, the Southern inmates were more frequently responsible of crimes against the person (38\%), while property crimes $(61 \%)$ were more recurrent in the Northern inmates.

The criminal behaviour among the elderlies has particular characteristics and it is growing fast. Probably, the raise of elderly prisoners is only related to the rapid aging of general populations with the increasing life expectancy ${ }^{17}$. Nowadays this phenomenon is not fully studied, and it is not known quantitatively in absolute terms. From 1995 to 2004 the elder inmates over 55 in the USA grew by $126 \%$, despite the incidence of elder crime remains stable at $4 \%{ }^{18}$. According to Taylor and Parrott ${ }^{19}, 4 \%$ of inmates in England are 55 and over. Other authors ${ }^{20,21}$ believe that these estimates are not really representative of the real percentage of offences committed by older people. In 
fact, public opinion is more indulgent with elderly than with young offenders and alternative measures to detention are preferred rather than imprisonment ${ }^{20}$. There is a general tendency to underestimate the frequency of elderly criminals since law enforcement agencies are more reluctant to arrest older people or they prefer to give financial penalties rather than a custodial sentence ${ }^{20,21}$. In Italy from 2005 to 2018 the group of prisoners aged between 60-70 years increased from 2800 to 3800 and the aging index has risen from $3 \%$ to $17 \%{ }^{22}$.

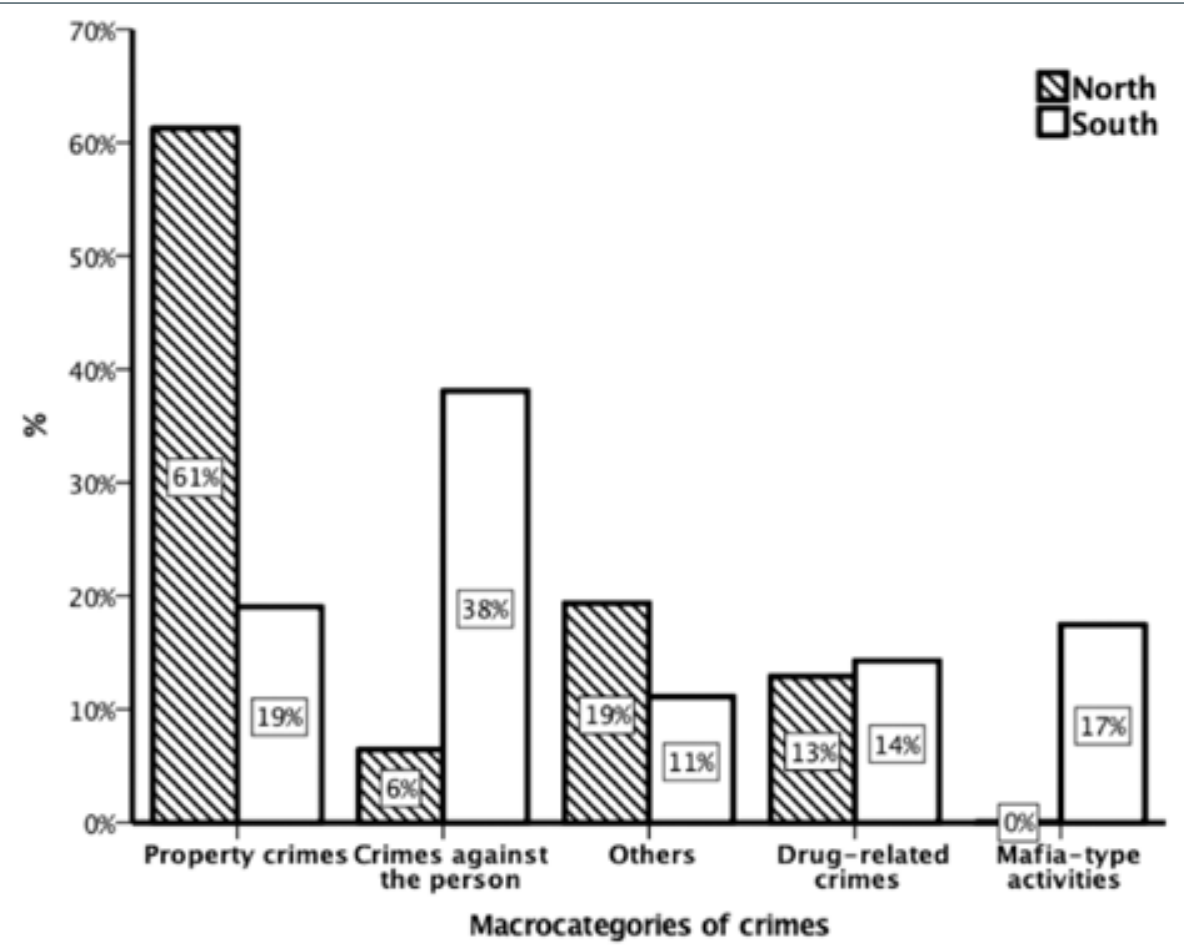

Figure 1. Distribution of categories frequency in the Northern and Southern study populations. A significant difference $(p<0.0001)$ was found between the two groups: the Southern inmates were more frequently responsible of crimes against the person, while property crimes were more recurrent in the Northern inmates.

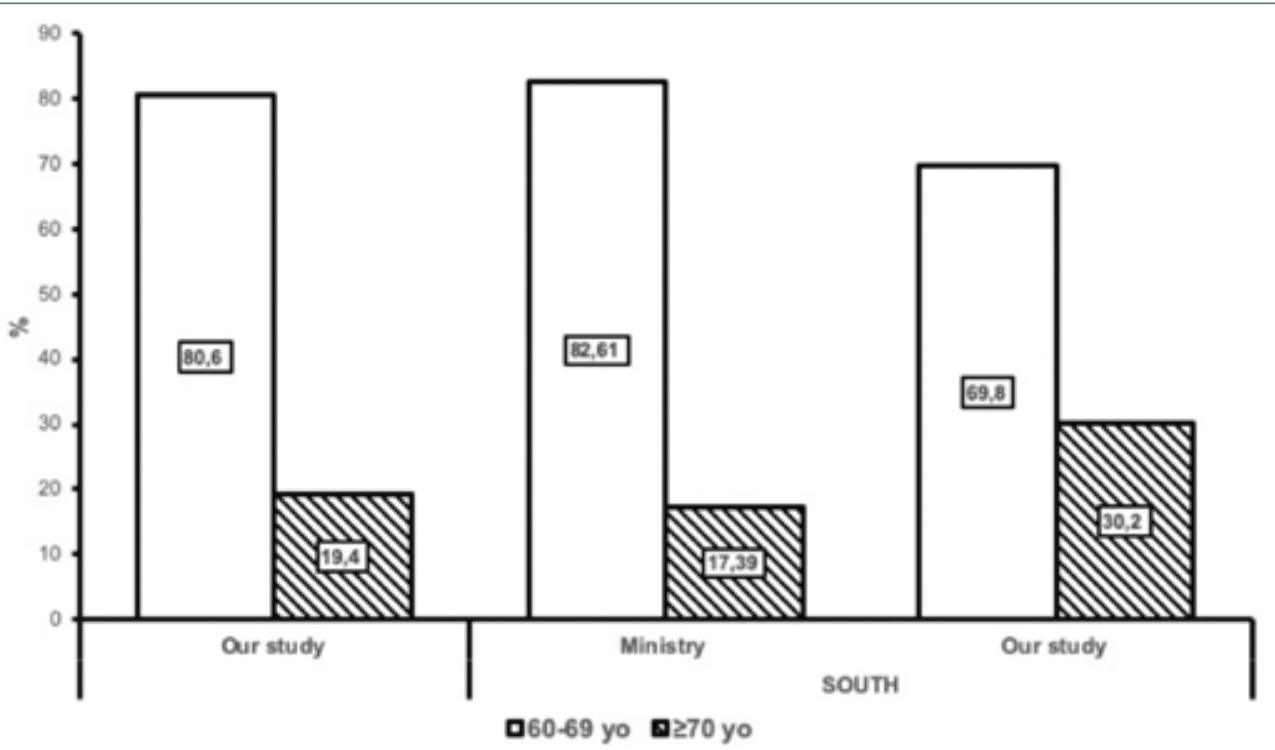

Figure 2. Distribution of inmates by age (60-69 vs $>=70$ years old) in the present study and in respect to 2017 Report of the Italian Justice and Law Ministry. 


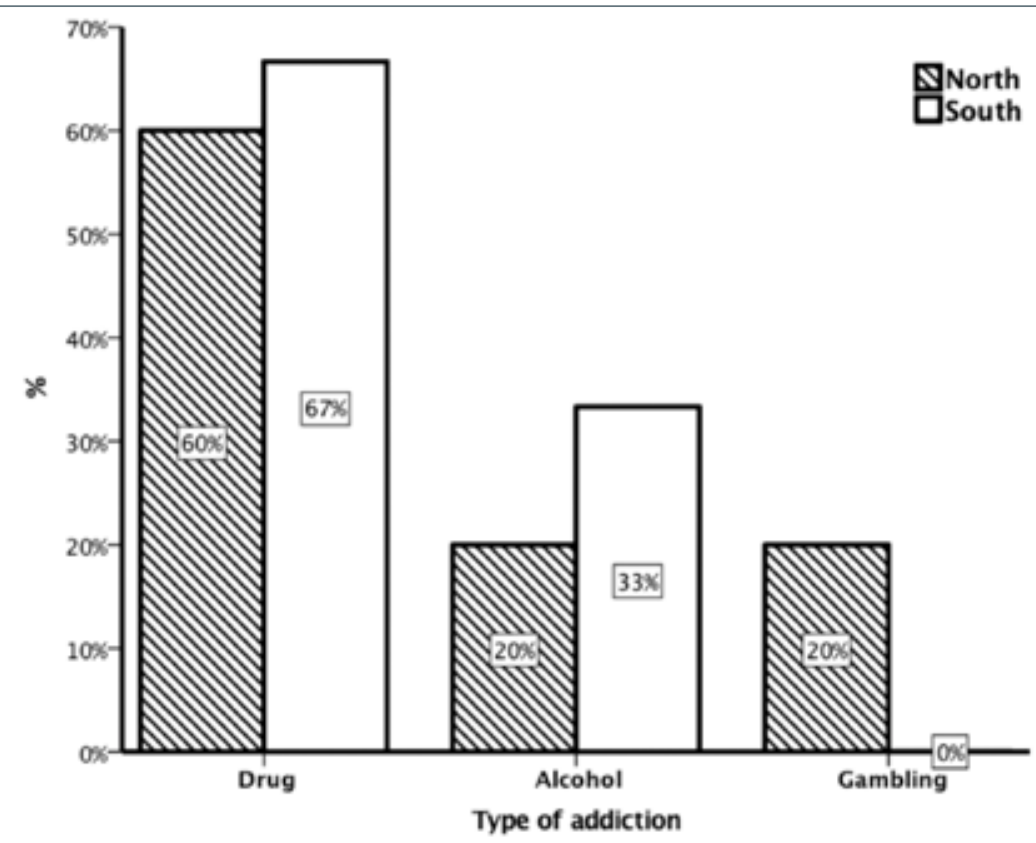

Figure 3. Types of addiction in the Northern and Southern study population.

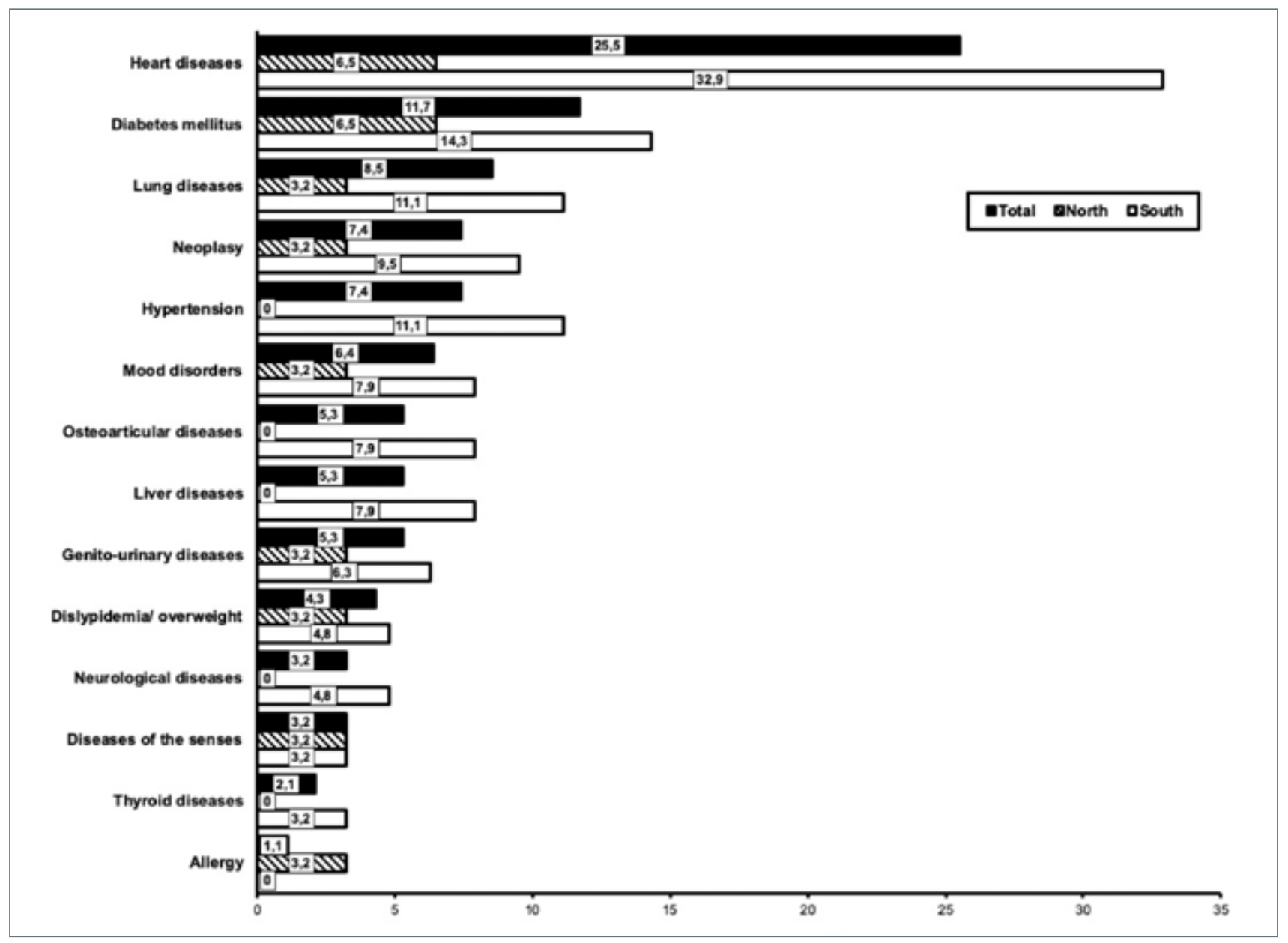

Figure 4. Distribution of diseases in the Southern and Northern study population. 
Data concerning the type of crimes committed by our sample showed a prevalence of property crimes with a percentage of $33.1 \%$; crimes against the person $27.7 \%$; other crimes 14\%; drug related crimes $13.8 \%$; and mafia-type activities $11.7 \%$ (Tab. II). For 10 subjects were found multiple crimes.

Unfortunately, in literature there are only few studies dealing with the criminal behaviour of the elderly. Barak et al. ${ }^{20}$ report a series of crimes committed from January 1987 to October 1992 by offenders older than 65 in Israel. Among the 9180 crimes totally recorded, the drug-related crimes are those more common (41\%) followed soon after by violent crimes (25\%), economicfinancial crimes (24.9\%), and sexual and driving crimes (9.1\%). However, only $0.34 \%$ of the overall crimes were committed by elderly people ${ }^{20}$. Similarly to our results, also in Israel the crimes most frequently committed by older prisoners are those against property, in particular: theft $(n=9)$; robbery $(n=9)$; receiving stolen goods $(n=5)$; fraud $(n=3)$; extortion ( $n=3)$; laundering $(n=3)$; counterfeiting $(n=1)^{21}$. Theft has been also found by Lindesay the most common type of crime in the US and the UK ${ }^{21}$.

According to the incarceration rate of elderly over 55, Sapp ${ }^{23}$ pointed out a steady increase of property crimes committed by elderly people up to $74 \%$ in USA since 1972 to 1982. Incarcerations for larceny-theft increased from 4.6 to $11.6 \%$ in that decade. In 1981 , about $10.6 \%$ of the elderly prisoners was due to theft, thus representing the most common crime ${ }^{23}$, as also observed in our study. Cullen et al. ${ }^{24}$ also confirmed that theft is the most common crime committed by the elderly based on the FBI Uniform Crime Reports. In 1982 the prevalence of theft was $78.62 \%$ that is five times higher than the aggravated assaults (13.73') that represent the second highest category of crimes ${ }^{24}$. In England and Wales, theft was committed by 21 and $46 \%$ of the elderly male and female prisoners respectively ${ }^{25}$. In our study only few women $(n=6,6.4 \%)$ were recruited. Therefore, we were not able to analyse the characteristics of the elder female inmates in Italy.

Feldmeyer and Steffensmeier ${ }^{26}$ also find that in America, in 2004 , about $45 \%$ of elderly people were arrested for theft, confirming that it remains one of the most common crimes for the elderly ${ }^{26}$, probably due to the elderly increasing precarious economic conditions ${ }^{23}$. The poor social status and financial conditions could lead elderly individuals to commit crimes in order to improve their lifestyle ${ }^{23}$. The elderly feels himself often disqualified because of their unemployment ${ }^{24}$ and the retirement age can provide disesteem, uselessness and unproductiveness ${ }^{24}$.

Compared to theft, robbery was poorly represented in the elder study group considered by Sapp $(0.5 \%)^{23}$ and by Fazel $(0.4 \%)^{25}$. In contrast in our survey the frequency of robbery was responsible of about $10 \%$ of the crimes. However, another Italian study showed that the property crimes were the most frequent category of crimes committed by the elderly prisoners from 2005 to $2018^{27}$.

The second most common category of offences committed by elderly prisoners in our survey was represented by the crimes against the person (27.7\%, Table II). Steffensmeier ${ }^{28}$ finds out that the rate of crimes against the person committed by the elderly was approximately $8 \%$ of the total crimes. In our survey, murder (13.8\%, Table II) was the most committed crime against the person. The rate of murders in USA was $4.6 \%$ of total incarcerations but the most common crime against the person among elderly prisoners ${ }^{23}$. Cullen et al. ${ }^{24}$ reported that the murders committed by over 65 years old people increase of $27 \%$ in the period 1967-1982. It has been suggested ${ }^{21}$ that homicide committed by elderly is often associated with depressive and paranoid symptoms. Most of them usually kill their wives and then attempt or complete suicide. Chronic alcohol abuse may lead to pathological jealousy and it can result in assaulting and killing the partner ${ }^{21}$. Dementia can also, occasionally, cause violent behaviour because of poor control of impulses and lack of sexual inhibition ${ }^{29-}$ ${ }^{31}$. In Turkey, $10 \%$ of people over 55 years of age were sentenced for homicide between 2003 and 2006 and 255 prisoners over 60 years of age (32\%) were found guilty for voluntary murder ${ }^{32}$.

Regarding sexual offences, Fazel ${ }^{25}$ points out that these types of crime are more common among older people than younger. They have been counted up to $7.4 \%$ of the total sex crimes and to $21.6 \%$ among the elderly inmates in England in $2003{ }^{25}$. Canadian Public Health Association ${ }^{33}$ reports higher percentages up to $76.1 \%$ among elder offenders sentenced for sexual assault, compared to $10.7 \%$ of people under 30 and $18.9 \%$ of people between 30 and 49 years of age. Victims are often children or people with disabilities ${ }^{33}$. However, although the high frequency of sexual crimes committed by elderly prisoners, the level of recidivism for this type of crimes is lower compared to young inmates ${ }^{25,34-}$ 36. This could be due to the decrease of sexual desire in the elderly ${ }^{34}$. In this regard, it has been proposed ${ }^{35}$ that recidivism for sexual abuse is inversely proportional to age, and there is no correlation with both intra and extra-family harassment ${ }^{37}$. Elderly sex offenders seem to have schizoid, obsessive-compulsive and avoidant traits compared to young subjects, supporting the hypothesis that sexual violence by elderly is more associated with personality traits than with mental or neurodegenerative diseases ${ }^{38}$. Only Lindesay ${ }^{21}$ argued that sexual crimes by elderly could be associated with cognitive decline 
and neurodegenerative diseases, such as dementia or Alzheimer's disease. In fact, dementia, including different symptoms (e.g. memory loss, personality changes, attention deficits, hallucinations, hypersexuality, agitation and aggression) has a very high prevalence in elderly inmates, reaching up to $30 \%$ of total elder inmates $5,20,39-43$. Cognitive and mental impairment can also explain the high prevalence of sexual crimes by elderly just because of the loss of self-control in containing aggressive and sexual impulses ${ }^{17}$. Coping strategies of elderly individuals could be damaged by stressful events such as fear of death, physical or mental disorders, loss of the partner or other family members, change of health status ${ }^{44}$. Last but not least, elder prisoners have a general tendency to alcoholism compared with young prisoners and they tend to be more aggressive and less able to face the stress $^{44}$. It is important to take into consideration also the changing in relationships and status of elderly people in order to understand the reason of violent crimes. In fact, aggressive behaviour occurs frequently in family context ${ }^{17}$. Aggressive reactions can be fostered by the exclusion of the elderly from the family context, by the humiliation related to the loss of active and productive roles and by the poor respect that family members could have towards them ${ }^{17}$.

Other crimes often committed also by the elderly are drug-related crimes. They are moderately present in our sample (13.8\%, Table II), represented by illicit traffic in drugs. Since 1980 up to 2004 the rate of this category of crime has increased from 7.9/100.000 to $37 / 100.000{ }^{26}$. Incarcerations for drug-related crimes rose from 1 to $6 \%$ of the total number of convictions, becoming one of the most represented categories of crimes ${ }^{26}$. Such trend can be mostly related to government anti-drug strategies adopted worldwide to fight drug trafficking with great severity ${ }^{45,46}$. In Israel, between 1987 and 1992, drug-related crimes were counted to be $41 \%$ of the total crimes, but none of them were committed by elderly probably because drug-free in childhood ${ }^{20}$. However, in the near future it is expected that these crimes could be more represented in elderly because of their exposure to drug use/ abuse ${ }^{20}$. Gross ${ }^{47}$ observed a relevant increase (from 902 to 16,168 incarcerations between 1971 and 2004) in drug-related crimes, quite exclusively linked to the age group 55-65, while in the age group over 65 years the increase was less significant (from 251 to 2,299). The Author explained such differences based on behavioural changes in elderly crimes and in the reluctant attitude of the police enforcements to arrest elderly individuals ${ }^{47}$. Drug-related crimes have been found to be the most common type of crimes in a study by Berger ${ }^{18}$, but only because intoxication and drunken driving were also included in this category.
Our survey showed a consistent tendency to recidivism, with $68.8 \%(n=64)$ of the sample having a previous sentence, compared to $31.2 \%(n=30)$ of primary criminals. It should be noted that, of the 64 recidivists, 18 had already been convicted for several crimes. These data are not in agreement with those provided by other authors ${ }^{17}$ who found few recidivists among the elderly belonging to the delinquent subculture and more individuals committing crimes for the first time (about 50\% of all crimes made by elderly). According to Aliustaoglu et al., elderly tend to recidivism less than young prisoners ${ }^{32}$. For inmates between 16 and 18-years recidivism is $70 \%$ higher compared to adults. It is around $27 \%$ for adults and then fells to $22 \%$ for prisoners between 50 and 64 years of age and, finally, drastically drops to $7.4 \%$ for people over 65 years ${ }^{32}$. For this small group of elder recidivists, criminality is the only lifestyle as they do not know any other way how to live ${ }^{48}$. They represent a major challenge for health professionals in prison, because they usually have problems of alcoholism, drug abuse, sedentary lifestyle and all these factors predispose them to serious health problems during the period of detention ${ }^{49-52}$. They are often characterized by chronic disorders such as heart disease, diabetes and hypertension ${ }^{53,54}$, as showed in our survey where heart diseases and diabetes were the most common conditions.

\section{LIMITATIONS AND STRENGTHS}

The main limitation of this survey is represented by the fact that every crime has been classified according to the Italian Penal code, for which no correspondence with international criminal laws has been always found. Another important limitation is represented by the small number of female elder inmates $(n=6,6.4 \%)$ recruited that did not allow to perform a specific analysis.

However, to the best of our knowledge this is the first survey on the characteristics and problems of Italian elderly offenders convicted in jail.

\section{CONCLUSIONS}

Our results are consistent with the national and international literature except for the high rate of recidivism, mostly related to the lifestyle in criminality of the elder inmates in this survey. This survey provides the first picture of the elder Italian inmates. Indeed, the understanding of the phenomenon is very important to address the penitentiary policy and to assess if the treatment of the inmates in jails fit well with the specific needs and rights of the elderly.

In the next future, further more extensive studies should be performed to better characterize the phenomenon, 
also in a gender-oriented point of view. In fact, committing crimes in older age is strongly different from being a criminal in young or adult age, especially for the complexity that per se characterizes the older population.

\section{References}

1 Eurostat 2019 (https://ec.europa.eu/eurostat/statisticsexplained/index.php?title=File:Population_age_structure_ by_major_age_groups,_2008_and_2018_(\%25_of_the_ total_population).png).

2 Istat. Noi Italia. 100 statistics to understand the country we live in, 2017 edition (http://noi-italia2017.istat.it).

3 Istat. Noi Italia. 100 statistics to understand the country we live in. 2019 edition (http://noi-italia2019.istat.it).

4 World Health Organization. Prisons and Health 2014 [cited in: 19/04/2019] (http://www.euro.who.int/_data/assets/ pdf_file/0005/249188/Prisons-and-Health.pdf).

5 Williams BA, Stern MF, Mellow J, et al. Aging in correctional custody: setting a policy agenda for older prisoner health care. Am J Public Health 2012;102:1475-81. https://doi. org/10.2105/AJPH.2012.300704

6 Istat. Detenuti adulti presenti nelle carceri italiane 2017 (http:// dati.istat.it/Index.aspx?DataSetCode=DCCV_DETENUTI\#).

7 Aday $\mathrm{RH}$. Aging prisoners' concerns toward dying in prison. Omega J Death Dying 2006;52:199-216. https:// doi.org/10.2190/CHTD-YL7T-R1RR-LHMN

8 Maschi T, Viola D, Morgen K. Unraveling trauma and stress, coping resources, and mental well-being among older adults in prison: empirical evidence linking theory and practice. Gerontologist 2014;54:857-67. https://doi. org/10.1093/geront/gnt069

9 Gal M. The physical and mental health of older offenders. FORUM on Corrections Research 2002;14 (https://www. csc-scc.gc.ca/research/forum/e142/e142d-eng.shtml).

10 Michel S, Gobeil R, McConnell A. Older incarcerated women offenders: social support and health needs. Research report R275. Ottawa, Ontario: Correctional Service of Canada 2012 (https://www.csc-scc. gc.ca/005/008/092/005008-0275-eng.pdf).

11 Williams BA, Lindquist $K$, Sudore $R L$, et al. Being old and doing time: functional impairment and adverse experiences of geriatric female prisoners. J Am Geriatr Soc 2006;54:702-7. https://doi.org/10.1111/j.15325415.2006.00662.x

12 Ravagnani L, Romano CA. Women in prison. Indagine sulla detenzione femminile in Italia. Lecce: Pensa Multimedia Editore 2013

13 Carnevale A, Di Tillio A. Medicina e carcere. Gli aspetti giuridici, criminologici, sanitari e medico-legali della pena. Milano: Giuffrè Editore 2006.

14 Franceschini A. La medicina penitenziaria. Trattato di medicina legale e scienze affini, vol. VIII, cap. CCLII, CEDAM, Padova 2009.

15 Ministero della Giustizia, Circolare n $3593 / 6043$ del 9 ottobre 2003 prot. N. 3593/6043; 2003.
16 Ponti G, Merzagorza Betsos I. Compendio di criminologia. Milano: Raffaello Cortina Editori 2008, pp. 451-7.

17 Ministero della Giustizia (https://www.giustizia.it/giustizia/ it/mg_1_14_1.page?facetNode_1=1_5_36\&contentld=SS T88846\&previsiousPage=mg_1_14).

18 Berger R. Criminal behavior among the elderly: a look into what people think about this emerging topic. Advances Aging Res 2018;7:1-16. https://doi.org/10.4236/ aar.2018.71001

19 Taylor PJ, Parrott JM. Elderly offenders. A study of agerelated factors among custodially remanded prisoners. $\mathrm{Br}$ J Psychiatry 1988;152:340-6. https://doi.org/10.1192/ bjp.152.3.340

20 Barak Y, Perry T, Elizur A. Elderly criminals: a study of the first criminal offense in old age. Int $\mathrm{J}$ Geriatr Psychiatry 1995;10:511-6.

21 Lindesay J. Elderly people and crime. Rev Clin Gerontology 1996;6:199-204. https://doi.org/10.1017/ S0959259800004664

22 Dipartimento Amministrazione Penitenziaria 31 dicembre 2018 (https://www.giustizia.it/giustizia/it/mg_1_14_1.pa ge?facetNode_1=0_2\&facetNode_2=0_2_10\&facetNode _3=0_2_10_2\&contentld=SST164963\&previsiousPage= mg_1_14).

23 Sapp AD. Arrests for major crimes. Trends and patterns for elderly offenders. J Offender Couns Serv Rehab 1989;13:19-44. https://doi.org/10.1300/J264v13n02_02

24 Cullen FT, Wozniak JF, Frank J. The rise of the elderly offender will a "new" criminal be invented? Crime Social Justice 1985;23:151-65.

25 Fazel S. Psychiatric aspects of crime and the elderly. In: Oxford Textbook of Old Age Psychiatry 2008, pp. 747-752 (https://www.researchgate.net/profile/Seena_Fazel/publication/236882642_Chapter_40_Oxford_Textbook_of_Old_ Age_Psychiatry/links/Odeec519e0fc5bee85000000.pdf).

26 Feldmeyer B, Steffensmeier D. Elder crime. Patterns and current trends, 1980-2004. Res Aging 2007;29:297-322. https://doi.org/10.1177/0164027507300802

27 Nuvoli G, Rocca G, Dijk B, et al. L'anziano autore di reato: aspetti epidemiologici e psicopatologici. Psicogeriatria 2018;2:69-82

28 Steffensmeier D. The invention of the 'new'senior citizen criminal. An analysis of crime trends of elderly males and elderly females, 1964-1984. Res Aging 1987;9:281-311. https://doi.org/10.1177/0164027587092006

29 Alagiakrishnan K, Lim D, Brahim A, et al. Sexually inappropriate behaviour in demented elderly people. Postgrad Med J 2005;81:463-6. https://doi.org/10.1136/ pgmj.2004.028043

30 Fazel S, Hope T, O'Donnell I, et al. Hidden psychiatric morbidity in elderly prisoners. Br J Psychiatry 2001;179:535-9. https://doi.org/10.1192/bjp.179.6.535

31 Williams BA, Ahalt C, Stijacic-Cenzer I, et al. Pain behind bars: the epidemiology of pain in older jail inmates in a county jail. J Palliat Med 2014;17:1336-43. https://doi. org/10.1089/jpm.2014.0160

32 Aliustaoglu FS, Ozdemir $\mathrm{M}$, Ince $\mathrm{H}$, et al. Criminal 
activities of the elderly in Turkey during the years 20002005. Arch Gerontol Geriatr 2011;53:e267-70. https://doi. org/10.1016/j.archger.2010.11.028

33 Canadian Public Health Association. A health care needs assessment of federal inmates in Canada. Canadian J Public Health 2004;95(Suppl 1):1-63 (https://pdfs.semanticscholar.org/55d9/d2e9801c9bc7b76074c994101a84fe707023. pdf?_ga=2.6221683.1328565045.1556278618174495410.1556278618).

34 Barbaree $\mathrm{H}$, Blanchard R, Langton $\mathrm{C}$. The development of sexual aggression through the life span: the effect of age on sexual arousal and recividism among sex offenders. Ann N Y Acad Sci 2003;989:59-71.

35 Hanson K. Recidivism and age: follow-up data from 4,673 offenders. J Interpers Violence 2002;17:1046-62.

36 Langan P, Schmitt E, Durose M. Recidivism of sex offenders released from prison in 1994. Bureau of Justice Statistics Bulletin NCJ 198281. US Department of Justice, Washington, DC 2003 (https://www.bjs.gov/content/pub/ pdf/rsorp94.pdf).

37 Fazel S, Langstrom N, Sjostedt G, et al. Risk factors for criminal recidivism in older sexual offenders. Sexual Abuse 2006;18:15967. https://doi.org/10.1177/107906320601800204

38 Fazel S, Hope T, O’Donnell I, et al. Psychiatric, demographic, and personality characteristics of elderly sex offenders. Psychol Med 2002;32:219-26. https://doi.org/10.1017/ s0033291701005153

39 Fazel S, Hope T, O'Donnell, et al. Health of elderly male prisoners: worse than the general population, worse than younger prisoners. Age Ageing 2001;30:403-7. https:// doi.org/10.1093/ageing/30.5.403

40 Heinik J, Kimhi R, Hes J. Dementia and crime: a forensic psychiatry unit study in Israel. Int $\mathrm{J}$ Geriat Psychiatry 1994;9:491-4. https://doi.org/10.1002/gps.930090608

41 Hucker SJ, Ben-Aron MH. Elderly sex offenders. In: Langevin, R, Ed. Erotic preference, gender identity and aggression in men: new research studies. Hillsdale, $\mathrm{NJ}$ : Laurence Erlbaum Associates 1985, pp. 211-23.

42 Rosner R, Wiederlight M, Harmon RB, et al. Geriatric offenders examined at a forensic psychiatry clinic. J Forensic Sci 1991;36:1722-31.

43 Roth M. Cerebral and mental disorders of old age as causes of anti-social behavior. In: De Reuck AUS, Porter R, Eds. CIBA Foundation: the mentally abnormal offender. Churchill, London 1968.
44 Sansom R. An examination of elder inmates services an aging crisis. Florida house of representative's criminal justice and corrections council committee on corrections representative Allen trillion, chair substantial research assistance, Florida Corrections Commission 1999 (http:// www.schmalleger.com/schmalleger/corrections/aginginmates.pdf).

45 Garland D. The culture of control: crime and social order in contemporary society. Chicago: University of Chicago Press 2001.

46 Steffensmeier DJ, Ulmer JT. Confessions of a dying thief: understanding criminal careers and illegal enterprises. New Brunswick, NJ: Transaction Publishers 2005.

47 Gross B. Elderly offenders: implications for corrections personnel. The Forensic Examiner. 2007;56-61. https:// doi.org/10.1177/0306624X07307783

48 Stojkovic S. Elderly prisoners: a growing and forgotten group within correctional systems vulnerable to elder abuse. J Elder Abuse Negl 2007;19:97-117. https://doi. org/10.1300/J084v19n03_06

49 Thomas DL, Thomas JA, Greenberg S. The graying of corrections: the management of older inmates. In: Stojkovic $\mathrm{S}$, Ed. Managing special populations in jails and prisons. Kingston, NJ: Civic Research Institute 2005.

50 Corbi G, Grattagliano I, Sabbà C, et al. Elder abuse: perception and knowledge of the phenomenon by healthcare workers from two Italian hospitals. Intern Emerg Med 2019;14:549-55. https://doi.org/10.1007/s11739-01902038-y

51 Corbi G, Grattagliano I, Catanesi R, et al. Elderly residents at risk for being victims or offenders. J Am Med Dir Assoc 2012;13:657-9. https://doi.org/10.1016/j. jamda.2012.05.012

52 Corbi G, Grattagliano I, Ivshina E, et al. Elderly abuse: risk factors and nursing role. Intern Emerg Med 2015;10:297303. https://doi.org/10.1007/s11739-014-1126-z

53 Nelson MB, Stanton SR. Managing chronic diseases and chemical detoxification within correctional settings. In: Stojkovic S, Ed. Managing special populations in jails and prisons. Kingston, NJ: Civic Research Institute 2005.

54 Campobasso CP, Bugelli V, De Micco F, et al. Sudden cardiac death in elderly: the post-mortem examination of senile myocardium and myocardial infarction. Journal of Gerontology and Geriatrics 2017;65:223-31. 